\title{
Physiological parameters of Piaractus mesopotamicus (Osteichthyes: Characidae) exposed to a biopesticide based on Bacillus thuringiensis
}

\author{
WAGNER S. MARIANO ${ }^{1,2}$, SAULO B. AZEVEDO ${ }^{3}$, FRANCISCO L. GOMES ${ }^{2}$, LIANA \\ B.D. LIMA ${ }^{2}$, SANDRO E. MORON ${ }^{2}$ and MARCOS TAVARES-DIAS ${ }^{1,4}$
${ }^{1}$ Programa de Pós-Graduação em Biodiversidade e Biotecnologia/BIONORTE, Universidade Federal do Amapá/UNIFAP, Rodovia Juscelino Kubitschek, Km 2, 68903-419 Macapá, AP, Brazil
${ }^{2}$ Universidade Federal do Tocantins/UFT, Campus Universitário de Araguaína, Avenida Paraguai, s/n, Setor Cimba, 77824-838 Araguaína, TO, Brazil
${ }^{3}$ Programa de Pós-Graduação em Zoologia, Museu Paraense Emílio Goeldi, Avenida Governador Magalhães Barata, 376, 66040-170 Belém, PA, Brazil
${ }^{4}$ Embrapa Amapá, Rodovia Juscelino Kubitschek, Km 6, 68903-419 Macapá, AP, Brazil

Manuscript received on May 15, 2018; accepted for publication on September 10, 2018

\begin{abstract}
How to cite: MARIANO WS, AZEVEDO SB, GOMES FL, LIMA LBD, MORON SE AND TAVARES-DIAS M. 2019. Physiological parameters of Piaractus mesopotamicus (Osteichthyes: Characidae) exposed to a biopesticide based on Bacillus thuringiensis. An Acad Bras Cienc 91: e20180474. DOI 10.1590/0001-3765201920180474.
\end{abstract}

\begin{abstract}
This study investigated the physiological effects of a pesticide based on Bacillus thuringiensis (Dipel-WP ${ }^{\circledR}$ ) added in the water and diet of Piaractus mesopotamicus during 24 and $48 \mathrm{~h}$. It was added $0.13 \mathrm{~g}$ of de $B$. thuringiensis per $\mathrm{kg}$ of commercial feed; and for the fish subjected to the biopesticide in the water of the tanks, it was added $0.13 \mathrm{~g} / \mathrm{L}$ of the biopesticide. Plasma levels of sodium, chloride, potassium, cholesterol, glucose, triglycerides, cortisol, total protein, alanine aminotransferase (ALT), aspartate aminotransferase (AST), hematocrit, hemoglobin, erythrocytes number, mean corpuscular volume (MCV) and mean corpuscular hemoglobin concentration $(\mathrm{MCHC})$, number of thrombocytes and leukocytes were determined. Cortisol, lactate, glucose, total protein, cholesterol, triglycerides, ALT, AST, sodium, potassium, hematocrit, hemoglobin, MCV, number of erythrocytes, leukocytes, lymphocytes, eosinophils and PAS-positive granular leukocytes suffered alterations derived from the addition of $B$. thuringiensis in water and diet of the fish. The toxicity of the concentrations of biopesticide in short-term exposure in water and diet of the fish led to blood alterations (increase or decrease). Therefore, care must be taken to avoid a possible prolonged contamination in the tanks of fish farming by agricultural pollution based on B. thuringiensis.
\end{abstract}

Key words: Biochemistry, Blood, Farm fish, Freshwater fish.

\section{INTRODUCTION}

Agricultural production systems in the contemporary world use high levels of pesticides, a growing practice in proportion to the increase in

Correspondence to: Marcos Tavares-Dias

E-mail: marcos.tavares@embrapa.br

ORCid: https://orcid.org/0000-0002-8376-1846 food production (Angelo et al. 2010, Gusmão 2013). Biopesticides have been used as an alternative to chemical pesticides and are considered more advantageous because they are less toxic and cause damage only to target insects. In addition, biopesticides are used in small concentrations and have a rapid decomposition (Angelo et al. 2010, Mariano et al. 2017, Lobo et al. 2018). Bacterial- 
based biopesticides have been used to control invertebrates, mainly pest insects that invade the various crops of soybean, corn and cotton (Mariano et al. 2015).

Currently, biopesticides based on Bacillus thuringiensis (Bt) have been widely used in biological control of crop pests in several countries since they are not considered to be environmentally harmful. Bacillus thuringiensis is a gram-positive bacterium of the family Bacillaceae with growth temperature range between 10 and $45^{\circ} \mathrm{C}$. The main characteristic that distinguishes this bacteria species from others of the same genus is the intracellular presence of protein crystals with entomopathogenic activities for several species of pest insects. Such protein crystals are the agents that act directly in the digestive tract of the target insects, leading them to death (Angelo et al. 2010, Lobo et al. 2018). Spores of Bt have advantages over vegetative cells because they remain stable for long periods, have the ability to grow rapidly, tolerate a wide range of physiological conditions, involve simple production processes, and are inexpensive. They can be used in commercial products because they are naturally suitable for ingestion by animals (Mendoza-Estrada et al. 2016).

Studies reported that $\mathrm{Bt}$ has no toxicity to non-target species, including fish (Jackson et al. 2002, Meher et al. 2002, Ahmad et al. 2011), but it produces toxic and highly specific proteins against protozoans, insects, helminths and mites of agricultural and veterinary importance (MendozaEstrada et al. 2016). Thus, Bt has been recommended for control of trematodes Centrocestus formosanus in ornamental fish (Mendoza-Estrada et al. 2016). However, for Oreochromis niloticus, exposure to Bt increased erythrocyte apoptosis (Grisolia et al. 2009) and in Colossoma macropomum, it decreased the number of total erythrocytes (Mariano et al. 2017). In Clarias gariepinus, intraperitoneal inoculation with Bt increased the leukocytes number (Omoya and Akharaiyi 2015). Therefore, little is known about the physiological effects of $\mathrm{Bt}$ in fish. Hematological parameters can provide information on physiological response of fish due to the close association of the circulatory system with the external environment. Blood analysis allows the assessment of health and potential pathological disorders that can affect the homeostasis of fish (Tavares-Dias and Mataqueiro 2004, RanzaniPaiva et al. 2013, Qadir et al. 2014, Omoya and Akharaiyi 2015, Fazio 2019), for example, when biopesticides are used. The aim of study was to investigate the effects of a pesticide based on $\mathrm{Bt}$ in blood parameters of Piaractus mesopotamicus, when administered in the tank water or diet.

\section{MATERIALS AND METHODS}

\section{FISH AND ACCLIMATION}

A total of 90 fingerlings of $P$. mesopotamicus $(121.5 \pm 28.9 \mathrm{~g})$ obtained from a commercial fish farming in Araguaína, Tocantins State (Brazil) was transported to the Laboratory of Zoophysiology and Biochemistry of the Federal University of Tocantins (UFT), in Araguaína (TO). These fishes were acclimated for 30 days in $500 \mathrm{~L}$ water tanks and were given fish feed containing $32 \%$ crude protein. A system of constant water was maintained in the tanks and the temperature was kept at $25^{\circ} \mathrm{C}$ and $\mathrm{pH}$ 7.0. The organic matter that accumulated at the bottom of the tanks was removed once a day, and dissolved oxygen level was of $6.2 \pm 2.3$ $\mathrm{mg} / \mathrm{L}$. This study was developed in accordance with the principles adopted by the Brazilian College of Animal Experimentation (COBEA) and were strictly according to the protocols and rules of the Committee on Ethics of Animal Use of the Embrapa Amapá ( $\left.\mathrm{N}^{\circ} 002-\mathrm{CEUA}\right)$.

PREPARATION OF THE DIETS WITH BIOPESTICIDE BASED ON Bacillus thuringiensis

Dipel-WP ${ }^{\circledR}$ biopesticide (Sumitomo Chemical, Brazil) containing spores of $B$. thuringiensis var. 
kurstaki was used in the diet for P. mesopotamicus. It was added $0.13 \mathrm{~g}$ of this biopesticide per $\mathrm{kg}$ of commercial feed (Mariano et al. 2017) to omnivorous fish containing $32 \%$ crude protein. The rations were then allowed to dry in a microbiological oven at $37^{\circ} \mathrm{C}$ during $12 \mathrm{~h}$ to activate the $\mathrm{Bt}$ spores. Later, a bacterial growth test was performed to confirm the presence of $\mathrm{Bt}$ in the prepared diets. A sterile swab was used in the prepared rations and the material was seeded in Petri dishes with Mueller-Hintom agar medium. After 24 hours in a microbiological oven at $37^{\circ} \mathrm{C}$, the Gram test was performed to identify $\mathrm{Bt}$. The rations were then used to feed P. mesopotamicus for 24 or $48 \mathrm{~h}$. These rations were prepared daily to avoid storage.

\section{EXPERIMENTAL DESIGN WITH BIOPESTICIDE}

BASED ON Bacillus thuringiensis

Two trials using Bt-based biopesticide were performed: one with addition in the feed and another with addition of the biopesticide in the culture tanks of $P$. mesopotamicus. For the trials with fish exposed to the $0.13 \mathrm{~g} / \mathrm{L}$ of biopesticide (Mariano et al. 2017) directly in the tank water $(150 \mathrm{~L})$ were used. Fish were divided in three groups: (1) control group, (2) group exposed to water with Bt during $24 \mathrm{~h}$ and (3) group exposed to water with Bt during $48 \mathrm{~h}$. For each group a total of 15 fishes were used, with 5 fishes per replicate and 3 replicates per treatment. The fish were fed $a d$ libitum two time every day, and no waste of ration was observed.

Fishes fed with ration containing the biopesticide were kept in tanks of $150 \mathrm{~L}$ and divided into three groups: (1) control group, (2) group fed with Bt during 24 and (3) group fed with Bt during $48 \mathrm{~h}$. For each group a total of 15 fishes were used, with 5 fishes per replicate and 3 replicates per treatment. The fishes were fed ad libitum two time every day and no wastes of ration was observed. The fishes of the control group were fed with commercial ration without the biopesticide, which was only moistened with water and dried in a microbiological oven at $37^{\circ} \mathrm{C}$, during $12 \mathrm{~h}$. This control group was used for comparison in both trials, with addition of the biopesticide in the feed and in water of cultivation.

During all trials the behavior (erratic swimming, lethargy, loss of balance and loss appetite) of the fish were analyzed.

A system of constant water was maintained in the tanks and the temperature was kept at 25.0 $\pm 1.1^{\circ} \mathrm{C}$ and $\mathrm{pH} 7.0 \pm 1.0$. The organic matter that accumulated at the bottom of the tanks was removed once a day and dissolved oxygen was 6.0 $\pm 2.1 \mathrm{mg} / \mathrm{L}$.

\section{BLOOD COLLECTION AND ANALYSIS}

Samples of blood were collected by puncture of the caudal vessel with heparinized syringes (5000 IU) and were divided in two aliquots for determination of blood parameters. One aliquot was used for determination of hematocrit by the microhematocrit method, hemoglobin concentration by the cyanometahemoglobin method and count of the total erythrocytes in Neubauer chamber. From these data, the hematimetric indices were determined: Mean Corpuscular Volume (MCV) and Mean Corpuscular Hemoglobin Concentration (MCHC). Blood smears were confectioned and stained with a panoptic staining (Laborclin $\left.{ }^{\circledR}\right)$ and used to determine the number of leukocytes and total thrombocytes (Ranzani-Paiva et al. 2013). The nomenclature of the leukocytes followed the recommendations of Tavares-Dias and Mataqueiro (2004).

Another blood aliquot was centrifuged to obtain plasma that was frozen at $-20^{\circ} \mathrm{C}$ and then used for biochemical analysis. Cortisol was determined using the DBC Kit (CAN-E-270 $\left.{ }^{\circledR}\right)$, which allowed direct quantitative determination of this enzyme-immunoassay and reading at $450 \mathrm{~nm}$ in a microplate reader. Concentrations of potassium 
$\left(\mathrm{K}^{+}\right)$, sodium $\left(\mathrm{NA}^{+}\right)$, chloride $\left(\mathrm{Cl}^{-}\right)$, glucose, lactate, total proteins, cholesterol, triglycerides, Aspartate Amino Transferase Enzyme (AST) and Enzyme Alanine Amino Transferase (ALT) were determined using kits from Labtest (MG, Brazil) for each purpose.

\section{STATISTICAL ANALYSIS}

All the data were initially assessed with regard to the assumptions of normal distribution and homoscedasticity, using the Shapiro-Wilk and Bartlett tests, respectively. Data with not a normal distribution were analyzed using Kruskal-Wallis followed by the Dunn test to compare the medians. Data with a normal distribution were analyzed using ANOVA-One way followed by the Tukey's test, to make comparisons between the means (Zar 2010).

\section{RESULTS}

During the trials of 24 and $48 \mathrm{~h}$ with $P$. mesopotamicus, there was no mortality or behavioral changes in the fish, except the loss of appetite. In fish exposed to tank water with Btbased biopesticide, cortisol levels after $24 \mathrm{~h}$ were similar $(\mathrm{p}>0.05)$ to the controls but decreased $(p<0.05)$ after $48 \mathrm{~h}$ in relation to control fish. Plasma concentration of lactate decreased $(p<0.05)$ after $24 \mathrm{~h}$ in relation to the control. Glucose levels decreased $(\mathrm{p}<0.05)$ after exposure of fish for 24 and $48 \mathrm{~h}$ to water containing $\mathrm{Bt}$ when compared to controls (Figure 1).

In fish fed diets containing Bt, cortisol levels were not affected ( $>0.05)$ after 24 and $48 \mathrm{~h}$, while lactate levels decreased $(\mathrm{p}<0.05)$ after $48 \mathrm{~h}$ when compared to control fish. However, glucose levels decreased $(p<0.05)$ after $24 \mathrm{~h}$ of feeding when compared to control but were similar $(p>0.05)$ after $48 \mathrm{~h}$ (Figure 1).

In fish exposed to water containing biopesticide based on Bt, plasma levels of total protein and
MCHC were not different $(\mathrm{p}<0.05)$ between the treatments. Cholesterol levels increased $(\mathrm{p}<0.05)$ after $48 \mathrm{~h}$ of exposure but were similar to control after $24 \mathrm{~h}$ while plasma levels of triglycerides decreased and AST. Plasma levels of ALT, sodium, hematocrit, hemoglobin and MCV increased $(\mathrm{p}<0.05)$ after 24 and 48 hours of exposure when compared to control. The total number of erythrocytes decreased after $48 \mathrm{~h}$ of exposure when compared to controls. Potassium concentration decreased $(\mathrm{p}<0.05)$ after $48 \mathrm{~h}$ of fish exposure to water containing Bt but was similar $(p>0.05)$ in fish after $24 \mathrm{~h}$ exposure and control. Chloride concentrations increased $(\mathrm{p}<0.05)$ in fish after $24 \mathrm{~h}$ of exposure to $\mathrm{Bt}$ but were similar to control after $48 \mathrm{~h}$ of exposure (Table I).

In P. mesopotamicus fed a diet containing Bt, levels of total protein, cholesterol, potassium and erythrocyte decreased $(\mathrm{p}<0.05)$ after 24 and $48 \mathrm{~h}$ compared to control, while hematocrit, hemoglobin and MCV increased $(\mathrm{p}<0.05)$. The MCHC and levels of sodium and chloride were similar $(p>0.05)$ between all treatments and controls. The levels of AST and ALT increased after $48 \mathrm{~h}$ of diet with Bt, while triglycerides levels increased after $48 \mathrm{~h}$ and decreased after $24 \mathrm{~h}$, compared to controls (Table I).

In fish exposed to water containing $\mathrm{Bt}$, the total number of thrombocytes did not presented alteration $(p>0.05)$ between treatments. Number of total leukocytes, lymphocytes and PASGL increased $(\mathrm{p}<0.05)$ after 24 and $48 \mathrm{~h}$ when compared to controls, but there were no differences between these evaluated periods. Number of monocytes and eosinophils increased $(p<0.05)$ after $24 \mathrm{~h}$ of exposure to water containing $\mathrm{Bt}$, but there were no differences ( $p>0.05$ ) after $48 \mathrm{~h}$ when compared to the control. In fish fed with diets containing Bt-based biopesticide, the number of total thrombocytes, lymphocytes, monocytes, eosinophils and PAS-GL was similar $(p>0.05)$ between treatments. However, the total number of leukocytes and neutrophils was similar $(p>0.05)$ 

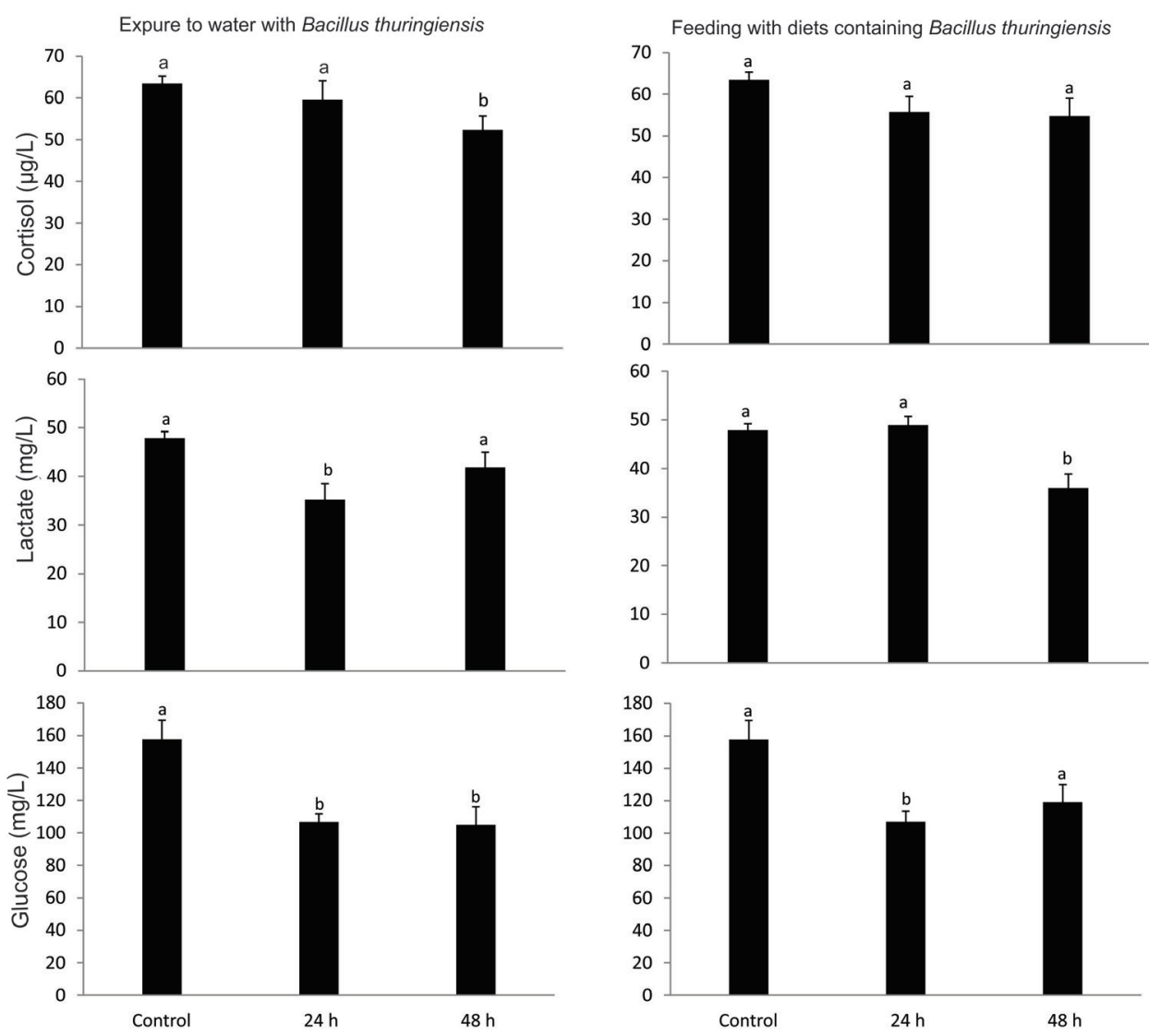

Figure 1 - Plasma levels of cortisol, lactate and glucose of Piaractus mesopotamicus exposed to water or diets containing biopesticide based on Bacillus thuringiensis. Values express mean and standard deviation. Different letters indicate differences by the Tukey test $(\mathrm{p}<0.05)$.

after 24 and $48 \mathrm{~h}$ feeding on Bt, but both were higher ( $p>0.05)$ than the controls (Table II).

\section{DISCUSSION}

Glucose, lactate and blood cortisol levels in fish have been often used as physiological indicator of stress (Wendelaar Bonga 1997, Barton 1997, 2002, Tavares-Dias and Mataqueiro 2004, Urbinati et al. 2015, Khansari et al. 2017). Ionic alterations can be caused by stress, and cortisol exerts both effects: mineralocorticoid and glucocorticoid (Barton 1997, 2002, Mommsen et al. 1999, Khansari et al. 2017). Thus, the secondary effects of stress can lead to metabolic adjustments in plasma levels of glucose, lactate and glycogen, as well as in levels of chloride, sodium, potassium, protein and osmolarity (Urbinati et al. 2015, Khansari et al. 2017). However, in P. mesopotamicus, the increase or decrease in $\mathrm{Na}^{+}, \mathrm{K}^{+}$and $\mathrm{Cl}^{-}$concentrations were not caused by cortisol, since this hormone presented reduction only after $48 \mathrm{~h}$ in fish exposure to water with biopesticide based on $\mathrm{Bt}$. The lactate levels also decreased only after $48 \mathrm{~h}$ of feeding with diet based on Bt. Possibly, these ionic alterations were caused by the reduction in feed intake and/or to mobilization of ions to vital organs (i.e. liver, kidney, gills and muscles) due to toxic effects of biopesticide based on Bt. Sarma et al. (2011) reported accumulation of ions in the vital organs of Channa punctatus exposed to pesticide, once the gills and kidneys represent the main organs responsible for osmotic regulation in 
TABLE I

Blood parameters of Piaractus mesopotamicus exposed to biopesticide based on Bacillus thuringiensis.

\begin{tabular}{|c|c|c|c|}
\hline \multicolumn{4}{|c|}{ Exposure to water with Bacillus thuringiensis } \\
\hline Parameters & Control & $24 \mathrm{~h}$ & $48 \mathrm{~h}$ \\
\hline Total protein $(\mathrm{g} / \mathrm{dL})$ & $7.2 \pm 0.4^{\mathrm{a}}$ & $5.8 \pm 0.8^{\mathrm{a}}$ & $7.5 \pm 0.3^{\mathrm{a}}$ \\
\hline Cholesterol (mg/dL) & $122.3 \pm 15.1^{\mathrm{a}}$ & $132.2 \pm 29.7^{\mathrm{ab}}$ & $174.2 \pm 29.8^{\mathrm{c}}$ \\
\hline Triglycerides (mg/dL) & $154.2 \pm 22.8^{\mathrm{a}}$ & $77.1 \pm 32.0^{\mathrm{b}}$ & $86.9 \pm 8.38^{\mathrm{b}}$ \\
\hline Sodium $(\mathrm{mmol} / \mathrm{L})$ & $105.3 \pm 52.7^{\mathrm{a}}$ & $382.1 \pm 49.4^{\mathrm{b}}$ & $318.7 \pm 28.4^{\mathrm{b}}$ \\
\hline Potassium (mmol/L) & $15.5 \pm 0.9^{\mathrm{a}}$ & $13.3 \pm 2.6^{\mathrm{ab}}$ & $11.3 \pm 0.9^{\mathrm{b}}$ \\
\hline Chloride (mmol/L) & $64.4 \pm 10.1^{\mathrm{a}}$ & $82.4 \pm 6.5^{\mathrm{b}}$ & $65.8 \pm 19.6^{\mathrm{ab}}$ \\
\hline AST (UL) & $11.7 \pm 7.32^{\mathrm{a}}$ & $25.4 \pm 7.5^{\mathrm{b}}$ & $19.0 \pm 6.34^{\mathrm{ab}}$ \\
\hline ALT (UL) & $9.7 \pm 7.6^{\mathrm{a}}$ & $21.1 \pm 9.0^{\mathrm{b}}$ & $24.9 \pm 13.7^{\mathrm{b}}$ \\
\hline Hematocrit (\%) & $21.3 \pm 3.5^{\mathrm{a}}$ & $31.23 \pm 3.2^{\mathrm{b}}$ & $32.8 \pm 3.3^{\mathrm{b}}$ \\
\hline Hemoglobin $(\mathrm{g} / \mathrm{dL})$ & $4.9 \pm 0.7^{\mathrm{a}}$ & $5.9 \pm 0.2^{\mathrm{b}}$ & $5.9 \pm 0.6^{\mathrm{b}}$ \\
\hline Erythrocytes $\left(\right.$ x $\left.10^{6} / \mu \mathrm{L}\right)$ & $2.039 \pm 0.150^{\mathrm{a}}$ & $1.870 \pm 0.100^{\mathrm{ab}}$ & $1.690 \pm 0.310^{\mathrm{b}}$ \\
\hline $\mathrm{MCV}(\mathrm{fL})$ & $105.4 \pm 20.4^{\mathrm{a}}$ & $155.6 \pm 29.1^{\mathrm{b}}$ & $185.9 \pm 46.6^{\mathrm{b}}$ \\
\hline $\mathrm{MCHC}(\mathrm{g} / \mathrm{dL})$ & $22.0 \pm 3.0^{\mathrm{a}}$ & $21.6 \pm 4.0^{\mathrm{a}}$ & $18.5 \pm 3.3^{\mathrm{a}}$ \\
\hline \multicolumn{4}{|c|}{ Feeding with diets containing Bacillus thuringiensis } \\
\hline Parameters & Control & $24 \mathrm{~h}$ & $48 \mathrm{~h}$ \\
\hline Total protein $(\mathrm{g} / \mathrm{dL})$ & $7.2 \pm 0.4^{\mathrm{a}}$ & $5.7 \pm 1.5^{\mathrm{b}}$ & $4.8 \pm 0.8^{\mathrm{b}}$ \\
\hline Cholesterol (mg/dL) & $122.3 \pm 15.1^{\mathrm{a}}$ & $88.1 \pm 18.1^{\mathrm{b}}$ & $79.7 \pm 18.1^{\mathrm{b}}$ \\
\hline Triglycerides (mg/dL) & $154.2 \pm 22.8^{\mathrm{a}}$ & $63.7 \pm 5.1^{\mathrm{b}}$ & $181.8 \pm 27.2^{\mathrm{c}}$ \\
\hline Sodium $(\mathrm{mmol} / \mathrm{L})$ & $105.3 \pm 52.7^{\mathrm{a}}$ & $110.4 \pm 39.2^{\mathrm{a}}$ & $78.4 \pm 12.9^{\mathrm{a}}$ \\
\hline Potassium (mmol/L) & $15.5 \pm 0.9^{\mathrm{a}}$ & $11.7 \pm 1.9^{\mathrm{b}}$ & $11.6 \pm 1.8^{\mathrm{b}}$ \\
\hline Chloride (mmol/L) & $64.4 \pm 10.1^{\mathrm{a}}$ & $53.8 \pm 10.7^{\mathrm{a}}$ & $45.6 \pm 6.4^{\mathrm{a}}$ \\
\hline $\operatorname{AST}(\mathrm{U} / \mathrm{L})$ & $11.7 \pm 7.32^{\mathrm{a}}$ & $24.0 \pm 6.31^{\mathrm{a}}$ & $77.1 \pm 21.0^{\mathrm{b}}$ \\
\hline ALT (U/L) & $9.7 \pm 7.6^{\mathrm{a}}$ & $16.1 \pm 6.3^{\mathrm{ab}}$ & $26.7 \pm 10.2^{\mathrm{b}}$ \\
\hline Hematocrit (\%) & $21.3 \pm 3.5^{\mathrm{a}}$ & $28.8 \pm 3.6^{\mathrm{b}}$ & $32.3 \pm 2.6^{\mathrm{b}}$ \\
\hline Hemoglobin (g/dL) & $4.9 \pm 0.7^{\mathrm{a}}$ & $5.4 \pm 0.7^{\mathrm{ab}}$ & $6.0 \pm 0.7^{\mathrm{b}}$ \\
\hline Erythrocytes $\left(\mathrm{x} 10^{6} / \mu \mathrm{L}\right)$ & $2.039 \pm 0.150^{\mathrm{a}}$ & $1.700 \pm 0.210^{\mathrm{b}}$ & $1.660 \pm 0.220^{\mathrm{b}}$ \\
\hline $\mathrm{MCV}(\mathrm{fL})$ & $105.4 \pm 20.4^{\mathrm{a}}$ & $173.1 \pm 44.6^{\mathrm{b}}$ & $196.5 \pm 20.6^{\mathrm{b}}$ \\
\hline $\mathrm{MCHC}(\mathrm{g} / \mathrm{dL})$ & $22.0 \pm 3.0^{\mathrm{a}}$ & $19.8 \pm 3.8^{\mathrm{a}}$ & $18.7 \pm 2.0^{\mathrm{a}}$ \\
\hline
\end{tabular}

Values express means \pm standard deviation. AST: Aspartate Amino Transferase, ALT: Alanine Amino Transferase, MCV: Mean corpuscular volume, MCHC: Concentration of mean corpuscular hemoglobin. Different letters, in the same line, indicate differences by the Tukey test $(\mathrm{p}<0.05)$.

freshwater fish. In addition, the feeding also plays an important role in ionoregulation and in other blood parameters of the fish (Liew et al. 2015).

In general, the plasma levels of total protein, triglycerides, glucose and cholesterol in P. mesopotamicus fed Bt-containing ration were reduced, probably due to reduction in feed intake, which affects the energy demand of fish.
Analyses of the activity of specific enzymes has been used to verify how the metabolism of animals reacts to different conditions, being possible to diagnose adverse metabolic conditions (Sampath et al. 2002, Kori-Siakpere et al. 2010, Qadir et al. 2014, Liew et al. 2015). The enzymes AST and ALT are important in the process of catabolism of amino acids and are available in the blood when 
TABLE II

Thrombocytes and leukocytes of Piaractus mesopotamicus exposed to biopesticide based on Bacillus thuringiensis.

\begin{tabular}{|c|c|c|c|}
\hline \multicolumn{4}{|c|}{ Exposure to water with Bacillus thuringiensis } \\
\hline Parameters & Control & $24 \mathrm{~h}$ & $48 \mathrm{~h}$ \\
\hline Thrombocytes $(\mu \mathrm{L})$ & $118,363 \pm 269,630^{\mathrm{a}}$ & $141,457 \pm 39,475^{\mathrm{a}}$ & $140,107 \pm 31,273^{\mathrm{a}}$ \\
\hline Leukocytes $(\mu \mathrm{L})$ & $82,268 \pm 8033^{\mathrm{a}}$ & $196,099 \pm 51,700^{\mathrm{b}}$ & $191,208 \pm 58,213^{\mathrm{b}}$ \\
\hline Lymphocytes $(\mu \mathrm{L})$ & $31,999 \pm 4816^{\mathrm{a}}$ & $75,122 \pm 24,671^{b}$ & $101,390 \pm 28,526^{\mathrm{b}}$ \\
\hline Neutrophils $(\mu \mathrm{L})$ & $37,973 \pm 7349^{\mathrm{a}}$ & $83,781 \pm 25,467^{b}$ & $68,680 \pm 24,644^{\mathrm{b}}$ \\
\hline Monocytes $(\mu \mathrm{L})$ & $3464 \pm 1250^{\mathrm{a}}$ & $12,736 \pm 4142^{\mathrm{b}}$ & $5889 \pm 2236^{\mathrm{a}}$ \\
\hline Eosinophils $(\mu \mathrm{L})$ & $5284 \pm 2067^{\mathrm{a}}$ & $13,604 \pm 3236^{\mathrm{b}}$ & $3393 \pm 1675^{\mathrm{a}}$ \\
\hline PAS-GL $(\mu \mathrm{L})$ & $3548 \pm 1450^{\mathrm{a}}$ & $10,865 \pm 6492^{b}$ & $11,856 \pm 4255^{\mathrm{b}}$ \\
\hline \multicolumn{4}{|c|}{ Feeding with diets containing Bacillus thuringiensis } \\
\hline Parameters & Control & $24 \mathrm{~h}$ & $48 \mathrm{~h}$ \\
\hline Thrombocytes $(\mu \mathrm{L})$ & $118,363 \pm 269,630^{\mathrm{a}}$ & $146,611 \pm 31,540^{\mathrm{a}}$ & $132,170 \pm 23,646^{\mathrm{a}}$ \\
\hline Leukocytes $(\mu \mathrm{L})$ & $82,268 \pm 8033^{\mathrm{a}}$ & $113,903 \pm 42,173^{\mathrm{ab}}$ & $158,166 \pm 53,891^{\mathrm{b}}$ \\
\hline Lymphocytes $(\mu \mathrm{L})$ & $31,999 \pm 4816^{\mathrm{a}}$ & $48,527 \pm 16,314^{\mathrm{a}}$ & $59,663 \pm 15,894^{\mathrm{a}}$ \\
\hline Neutrophils $(\mu \mathrm{L})$ & $37,973 \pm 7349^{\mathrm{a}}$ & $48,276 \pm 2481^{\mathrm{b}}$ & $75,199 \pm 31,408^{b}$ \\
\hline Monocytes $(\mu \mathrm{L})$ & $3464 \pm 1250^{\mathrm{a}}$ & $4164 \pm 941^{\mathrm{a}}$ & $5836 \pm 2321^{\mathrm{a}}$ \\
\hline Eosinophils $(\mu \mathrm{L})$ & $5284 \pm 2067^{\mathrm{a}}$ & $4918 \pm 1750^{\mathrm{a}}$ & $5617 \pm 2460^{\mathrm{a}}$ \\
\hline PAS-GL $(\mu \mathrm{L})$ & $3548 \pm 1345^{\mathrm{a}}$ & $8018 \pm 1690^{\mathrm{a}}$ & $11,851 \pm 4345^{\mathrm{a}}$ \\
\hline
\end{tabular}

Values express means \pm standard deviation. PAS-GL: PAS-positive granular leukocytes. Different letters, in the same line, indicate differences by the Dunn test $(\mathrm{p}<0.05)$.

there are tissue damages, mainly in hepatocytes (Sampath et al. 2002, Kori-Siakpere et al. 2010, Bawa et al. 2017). In P. mesopotamicus exposed to biopesticide based on $\mathrm{Bt}$, the increase in plasma levels of ALT suggests possible hepatic damages, since this enzyme is found predominantly in the liver (Kori-Siakpere et al. 2010, Bawa et al. 2017, Uncumusaoğlu 2018). In addition, changes in AST plasma levels suggests that the heart and skeletal muscles can had be affected by the action of Bt. However, it has been reported that biopesticides based on Bt are not toxic to fish (Jackson et al. 2002, Meher et al. 2002, Ahmad et al. 2011).

The hematocrit is a good indicator of the adverse effects of environmental factors to fish (Tavares-Dias and Mataqueiro 2004, RanzaniPaiva et al. 2013). In P. mesopotamicus exposed to biopesticide based on $\mathrm{Bt}$, it was found a decrease in the number of total erythrocytes, but with increased hematocrit, hemoglobin concentration and MCV as compensatory effect. This increase in hematocrit was caused by an increase in the number of immature erythrocytes (erythroblasts), as indicated by the increase in MCV, but no change in amount of hemoglobin by erythrocytes occurred, as indicated by no change in MCHC levels. Similarly, in Colossoma macropomum fed diet containing $20 \mathrm{mg} / \mathrm{L}$ biopesticide based on $\mathrm{Bt}$ per $\mathrm{kg}$ ration, a decline in the number of total erythrocytes but no change in hematocrit and hemoglobin concentration was reported (Mariano et al. 2017). In O. niloticus, exposure to $\mathrm{Bt}$ increased erythrocytes apoptosis (Grisolia et al. 2009), which may reduce the number of erythrocytes in fish exposed to biopesticide based on Bt. These data indicated that biopesticide based on $B$. thuringiensis have adverse effects on the physiology of fish. The disparity in the toxic potential of biopesticides based on Bt may perhaps be related to the differences in susceptibility and tolerance related to fish species. In addition, the 
magnitude of toxic effects of biopesticides also may be related to size of fish. However, these issues need still be investigated.

Piscine thrombocytes are cells responsible for hemostasis and are involved secondarily in immune defense (Tavares-Dias and Mataqueiro 2004, Ranzani-Paiva et al. 2013, Fazio 2019). In P. mesopotamicus exposed to biopesticide based on $\mathrm{Bt}$, the number of total thrombocytes was not affected, indicating that hemostasis was not impaired. The pesticide can change the functions of vital organs such as liver and kidney, disrupting the hemostatic function in fish exposed (Qadir et al. 2014); however, studies on biopesticides based on Bt have not carried out until the present moment.

In fish, stress response is related to a decreased function of the immune system, but it is dependent on the intensity and duration of the stressor. Consequently, an activation of the immune cells may also occur (Barton 2002, Tort 2011, Urbinati et al. 2015). Leukocytes are particularly useful in studies of physiology because they are altered by stress and can be directly related to stress hormone levels (Davis et al. 2008, Khansari et al. 2017, Fazio 2019). However, in P. mesopotamicus there were alterations in the number of leukocytes without increase in cortisol levels. Fish exposed to water with biopesticide based on Bt had leukocytosis caused by the increase in numbers of lymphocytes, neutrophils, monocytes, eosinophils and PAS-GL. In contrast, subcutaneous inoculation with $100 \mu \mathrm{L}$ of $10^{6} \mathrm{CFU} / \mathrm{mL}$ Bt caused leukopenia due to a decrease in the percentage of monocytes, neutrophils, and eosinophils in blood of Clarias gariepinus (Omoya and Akharaiyi 2015). Therefore, such differences in these results may be related to the pathway of $\mathrm{Bt}$ exposure and fish species.

\section{CONCLUSIONS}

Concentrations of the biopesticide based on $\mathrm{Bt}$ used in water and diet, in short exposure time, led to blood alterations due to toxicity, which affected the homeostasis of $P$. mesopotamicus. Therefore, as biopesticide based on Bt was toxic for fish exposed, due to the close relationship of fish with the aquatic environment and the dispersion of them in agriculture, care must be taken to avoid a possible contamination by these agricultural pollutant in fish farming tanks.

\section{ACKNOWLEDGMENTS}

M. Tavares-Dias was granted a Research Fellowship (\# 303013/2015-0) from the Conselho Nacional de Desenvolvimento Científico e Tecnológico (CNPq, Brazil).

\section{AUTHOR CONTRIBUTIONS}

WSM contributed with the data collection and text elaboration. SBA, FLG, LBDL and SEM contributed with execution of trials. MTD was the coordinator of this work.

\section{REFERENCES}

AHMAD MM, ALI SRA, MASRI MMM, GHAZALI R AND WAHID MB. 2011. Ecotoxicity of Bacillus thuringiensis, Terakil- ${ }^{\circledR}$ and Teracon- $1^{\circledR}$ against freshwater fish, tilapia nilotica. J Oil Palm Res 23: 1036-1039.

ANGELO EA, VILAS-BOAS GT AND CASTRO-GOMEZ RJH. 2010. Bacillus thuringiensis: características gerais e fermentação. Semina: Ciênc Agrár 31(4): 945-958.

BARTON BA. 1997. Stress in finfish: past, present and future a historical perspective. In: Iwama GK, Pickering AD, Sumpter JP and Schreck CB (Eds), Fish stress and health in aquaculture. Cambridge: Cambridge University Press, p. 1-33.

BARTON BA. 2002. Stress in fishes: a diversity of responses with particular reference to changes in circulating corticosteroids. Integ Comp Biol 42: 517-525.

BAWA V, KONDAL JK, HUNDAL SS AND HARPINDER K. 2017. Biochemical and histological effects of glyphosate on the liver of Cyprinus carpio (Linn.). Amer J Life Sci. Special Issue: Environmental Toxicology 5: 71-80.

DAVIS AK, MANEY DL AND MAERZ JC. 2008. The use of leukocyte profiles to measure stress in vertebrates: a review for ecologists. Funct Ecol 22: 760-772.

FAZIO F. 2019. Fish hematology analysis as an important tool of aquaculture: A review. Aquaculture 500: 237-242. 
GRISOLIA CK, OLIVEIRA-FILHO EC, RAMOS FR, CRUZLOPES MC, MUNIZ DHF AND MONNERAT RG. 2009. Acute toxicity and cytotoxicity of Bacillus thuringiensis and Bacillus sphaericus strains on fish and mouse bone marrow. Ecotoxicology 18: 22-26.

GUSMÃO FP. 2013. Biopesticida à base de Bacillus thuringiensis. USP, Lorena (SP), $42 \mathrm{p}$.

JACKSON JK, HORWITZ RJ, BERNARD W AND SWEENEY BW. 2002. Effects of Bacillus thuringiensis israelensis on black flies and nontarget macroinvertebrates and fish in a large River. Trans Am Fish Soc 131:910-930.

KHANSARI AR, BALASCH JC, REYES-LÓPEZ FE AND TORT L. 2017. Stressing the inflammatory network: immuno-endocrine responses to allostatic load in fish. $\mathrm{J}$ Marine Sci Res Tecnol 1: 002.

KORI-SIAKPERE O, IKOMI RB AND OGBE MG. 2010. Variations in alanine aminotransferase and aspartate aminotransferase activities in African catfish: Clarias gariepinus (Burchell, 1822) at different sublethal concentrations of potassium permanganate. Sci Res Essays 5(12): 1501-1505.

LIEW HJ, FAZIO A, FAGGIO C, BLUST R AND DE BOECK G. 2015. Cortisol affects metabolic and ionoregulatory responses to a different extent depending on feeding ration in common carp, Cyprinus carpio. Comp Bioch Physiol (Part A) 189: 45-57.

LOBO KS, SOARES-SILVA J, SILVA MC, TADEI WP, POLANCZYK RAAND PINHEIRO VCS. 2018. Isolation and molecular characterization of Bacillus thuringiensis found in soils of the Cerrado region of Brazil, and their toxicity to Aedes aegypti larvae. Rev Brasil Entomol 62: $5-12$.

MARIANO WS, MORON S, GARCIA RG AND TAVARESDIAS M. 2015. Impactos de pesticidas e biopesticidas na aquicultura. In: Tavares-Dias M and Mariano WS (Orgs), Aquicultura no Brasil: novas perspectivas. São Carlos: Editora Pedro \& João, p. 625-644.

MARIANO WS, SOUSA FLG, TAVARES-DIAS M, RODRIGUES RC, AZEVEDO SB AND LIMA JO. 2017. Estudo hematológico de tambaqui (Colossoma macropomum) submetido à concentração subletal de biopesticida a base de Bacillus thuringiensis. Rev Sodebras 12: 161-167.

MEHER SM, BODHANKAR SL, ARUNKUMAR A, DHULEY JN, KHODAPE DJ AND NAIK SR. 2002. Toxicity studies of microbial insecticide Bacillus thuringiensis var. kenyae in rats, rabbits, and fish. Inter J Toxicol 21: 99-105.
MENDOZA-ESTRADA LJ, HERNÁNDEZ-VELÁZQUEZ VM,ARENAS-SOSAI, FLORES-PÉREZ FI, MORALESMONTOR J AND PEÑA-CHORA G. 2016. Anthelmintic effect of Bacillus thuringiensis strains against the gill fish trematode Centrocestus formosanus. BioMed Res Inter Volume 2016, Article ID 8272407, 9 pages.

MOMMSEN TP, VIJAYAN MM AND MOON TW. 1999. Cortisol in teleosts: dynamics, mechanisms of action, and metabolic regulation. Rev Fish Biol Fish 9: 211-268.

OMOYA FO AND AKHARAIYI FC. 2015. Physiological changes in Clarias gariepinus induced with Bacillus species used as biological agent in aquatic environment. J Scien Res Reports 7(2): 117-128.

QADIR S, LATIF A, ALI M AND IQBAL F. 2014. Effects of imidacloprid on the hematological and serum biochemical profile of Labeo rohita. Pakistan J Zool 46(4): 1085-1090.

RANZANI-PAIVA MJT, PÁDUA SB, TAVARES-DIAS M AND EGAMI MI. 2013. Métodos para análise hematológica em peixes. Eduem: Maringá, 135 p.

S A M P A H H, RAM E H M A N D MANAVALARAMANUJAM M. 2002. Responses of plasma transaminase activity in Cyprinus carpio var. communis to mercury toxicity. J Indian Fish Assoc 29: 7-13.

SARMA K, PAL AK AND BARUAH K. 2011. Alterations of the ionic composition in different organs of spotted murrel (Channa punctatus) exposed to sublethal concentration of endosulfan. Turkish J Fish Aqua Sci 11: 93-99.

TAVARES-DIAS M AND MATAQUEIRO MI. 2004. Características hematológicas, bioquímicas e biométricas de Piaractus mesopotamicus Holmberg, 1887 (Osteichthyes: Characidae) oriundos de cultivo intensivo. Acta Sci Biol Sci 26(2): 157-162.

TORT L. 2011. Stress and immune modulation in fish. Dev Comp Immunol 35: 1366-1375.

UNCUMUSAOĞLU AA. 2018. Blood biochemical changes in common carp (Cyprinus carpio Linnaeus, 1758) fed different levels of copper sulphate and zeolite. Turkish J Agricult - Food Sci Technol 6(1): 1-6.

URBINATI EC, ZANUZZO FS, SERRA M, WOLKERS CP AND SABIONI RE. 2015. Avanços da fisiologia do estresse e suas implicações em espécies nativas. In: Tavares-Dias M and Mariano WS (Eds), Aquicultura no Brasil: novas perspectivas. São Carlos: Editora Pedro \& João, p. 381-416.

WENDELAAR BONGA SE. 1997. The stress response in fish. Physiol 77: 591-625.

ZAR JH. 2010. Biostatistical analysis. $5^{\text {th }}$ ed., New Jersey: Prentice Hall, 944 p. 